\title{
Hollow Fiber Device
}

National Cancer Institute

\section{Source}

National Cancer Institute. Hollow Fiber Device. NCI Thesaurus. Code C49953.

Any device made from a fiber with a hollow center, particularly those for cell propagation in culture. 